\title{
THE ACID-BASE INTERACTION ROLE IN THE PROCESSES OF THE FILLED DIANE EPOXY RESIN STRUCTURING
}

\author{
Yuliya Danchenko ${ }^{1, *}$, Mariya Kachomanova ${ }^{1}$, Yelena Barabash ${ }^{1}$
}

https://doi.org/10.23939/chcht12.02.188

\begin{abstract}
The processes of the ED-20 diane epoxy resin structuring, containing disperse oxidic fillers and modifiers are studied with the help of the rotational viscometry method. It is shown that the acid -base interactions between the functional groups of the resin part molecules and the active centers of the fillers surface play the defining role in these processes. The structure degree is defined both by the total amount of the surface active centers, and their $\mathrm{pKa}$ value. It is approved that the diffusive phenomena intensity is defined by the acid force of the fillers hydroxyl groups whereas the share of the volume effects in the compositions is small.
\end{abstract}

Keywords: diane epoxy resin, disperse oxide filler, acidbase interactions, active center, dynamic viscosity.

\section{Introduction}

The materials based on the modified diane epoxy resin with the disperse oxides as their fillers are widely used in constructions. Unique characteristics and simple technologies enable to use them as the injection structures for building and construction repair, restoration and reconstruction, water proof and facing materials as well as metal, wooden, brick and concrete building constructions and detail impregnation, pasting and covering.

The structural organization of various diane epoxy resin systems is studied rather detailed [1-6]. It is shown that in virtue of the hardeners lack, the intermolecular interactions existence (IIE) in the resins as well as the molecules tendency to the association (to supramolecular structuring) can cause their non-Newtonian behavior [1-3, 6]. In addition, the physical and chemical interactions (PCI) on the interphase [1-5] significantly influence the rheological behavior and the composition features in the filled compositions. It is known that the structuring processes in the filled diane epoxy resin systems are

\footnotetext{
${ }^{1}$ Kharkiv National University of Civil Engineering and Architecture, 40 Sumska St., 61002 Kharkiv, Ukraine

*u_danchenko@ukr.net

(C) Danchenko Yu., Kachomanova M., Barabash Ye., 2018
}

caused by three types of the interactions: volume, diffusive and interphase ones [3]. However, the questions connected with their nature and mechanisms are insufficiently covered in the literature and also there is no clarity in the matter of any phenomena prevalence. It especially concerns the multicomponent systems with a large number of various functional polar groups in resin molecules, modifiers and fillers surface. The compositions filled with the disperse oxides and based on the diane epoxy resin belong to such type of systems.

The polar functional groups presence both in the diane epoxy resin structure and on fillers surface causes a wide range of communications and interactions in the system. Nevertheless, some experimental data show that the greatest contribution to IIE and PCI is brought by the acid - base processes of Brønsted and Lewis character [7-11]. The incomplete acid-base interaction likely occurs while there are no polar solvents and in the context of the weak acids or Brønsted bases (OH-groups). At the same time, the transition of a proton to the basis, apparently, doesn't come from the acid, and the interaction comes to an end at the electrostatic or hydrogen communication formation stage, which energy varies within the vast bounds. Lewis interactions can happen between weak bases (ether, epoxy, amine, amide groups) and weak acids (metals atoms with a free orbital on fillers surface) [8]. It is assumed that these interactions are the cornerstone of the composition rheological features, and also have a significant effect on the structure and the cured material operational characteristics [9]. Therefore, the purpose of the current work is to find out the role of the acid-base interactions in the diane epoxy resin structuring processes with disperse oxide fillers.

\section{Experimental}

The filled compositions based on the ED-20 diane epoxy resin (Ukrainian state standard 2093-92) modified by the non-ionic surfactant of Amirol M (technical specification 38.301-48 49-97) were used as the objects of 
the research. Amirol $M$ is the mixture of the modified highest fatty acids of castor oil interaction products ( $\sim 5 \%$ of retsinol acid) and diethanol amide at $1773 \mathrm{~K}$. Its addition into compositions enables to receive the injection materials with the possibility of damp surfaces applying [12]. The air and dry disperse oxides of no more than 50-63 nanometers particles in size served as the fillers. They give the improved technological as well as physical and mechanical characteristics to the materials. The specific surface of the fillers was defined by the BET method (Brunauyer, Emmett and Teller). Some characteristics of the substances and the chemical composition of the fillers are given in Tables 1 and 2.

With the software package development for the molecular modeling there has been the possibility to research the spatial conception of the molecules mutual orientation in the self-organized systems and on the interphase. The IIE and PCI thermodynamic, power and kinetic parameters, giving the ideas of various model system nature $[12,13]$, can be set by the calculation within these programs. The IIE and PCI research on the interphase was conducted by means of the software package for the chemical HyperChem system molecular modeling. In this software package, well-known empirical methods of molecular mechanics as well as non- empirical and semi-empirical methods of quantum chemistry are used. The method of PM3 semi-empirical calculation, which enables the best result receiving for big hydrocarbonic systems, was chosen as the basic one. Furthermore, the rotational viscometer Reotest- 2 with the working knot "cylinder-cylinder" was used to provide the experimental assessment of the modeling results and the definition of the system structure degree. The value of the dynamic viscosity was defined with the accuracy of $\pm 4 \%$.

A number of physical and chemical methods were used with the purpose to research the nature and the characteristics of the disperse oxides surface. The X-ray phase analysis was carried out by means of the DRON-3 diffract meter at the CuKa-radiation. The nature of the superficial active centers as well as their acid - base characteristics were studied according to the complex technique including quantum and chemical modeling, $\mathrm{pH}$ - metric research of water suspensions and pK-photometric definition on the color indicators adsorption.

\section{Results and Discussion}

\subsection{Research of IM I in ED-20:Amirol M System}

The three-dimensional models of molecular complexes constructed with the function of geometrical optimization are shown in Fig. 1.

As follows from the modeling, the intermolecular distance and the molecules dipolar moments, the molecular complexes values, the enthalpies of the formation and the energy of the molecules interaction in complexes have been received. The energy of interaction of molecules was calculated by a difference:

$$
\begin{gathered}
\mathrm{A}+\mathrm{B} \leftrightarrow \mathrm{AB} \\
E_{\text {mutual }}=\Delta H_{\text {formation }}(\mathrm{AB})- \\
-\left[\Delta H_{\text {formation }}(\mathrm{A})+\Delta H_{\text {formation }}(\mathrm{B})\right] .
\end{gathered}
$$

Results of calculations are shown in Table 3.

Table 1

Characteristics of the substances used

\begin{tabular}{|l|c|c|}
\hline \multicolumn{1}{|c|}{ Characteristics } & ED-20 & Amirol M \\
\hline Average molecular weight, $\mathrm{g} / \mathrm{mol}$ & $390-430$ & 385 \\
\hline Epoxy content, $\%$ & 21.8 & - \\
\hline Density at $298 \mathrm{~K}, \mathrm{~kg} / \mathrm{m}^{3}$ & $1160-1250$ & $960-1110$ \\
\hline Dynamic viscosity at $298 \mathrm{~K}, \mathrm{~Pa} \cdot \mathrm{s}$ & 23.0 & 1.5 \\
\hline
\end{tabular}

Table 2

Fillers chemical composition

\begin{tabular}{|l|c|c|c|c|c|c|c|c|}
\hline \multirow{2}{*}{ Filler } & \multirow{2}{*}{$\begin{array}{c}\text { Specific surface } \\
S, \mathrm{~m}^{2} / \mathrm{g}\end{array}$} & \multirow{2}{*}{$\begin{array}{c}\text { Density } \\
\text { at } 298 \mathrm{~K}, \mathrm{~kg} / \mathrm{m}\end{array}$} & & \multicolumn{6}{|c|}{ Content of oxide, $\mathrm{wt} \%$} \\
\cline { 5 - 10 } & & & $\mathrm{SiO}_{2}$ & $\mathrm{Al}_{2} \mathrm{O}_{3}$ & $\mathrm{Fe}_{2} \mathrm{O}_{3}$ & $\mathrm{TiO}_{2}$ & $\mathrm{CaO}$ & $\mathrm{MgO}$ \\
\hline Diabase powder (DP) & 1.90 & 2850 & $45-76$ & $7-14$ & $4-15$ & - & $4-6$ & $2-17$ \\
\hline Red slime (RS) & 11.35 & 3350 & $4-5$ & $9-10$ & $70-74$ & $5-6$ & $20-22$ & $0.4-0.5$ \\
\hline
\end{tabular}




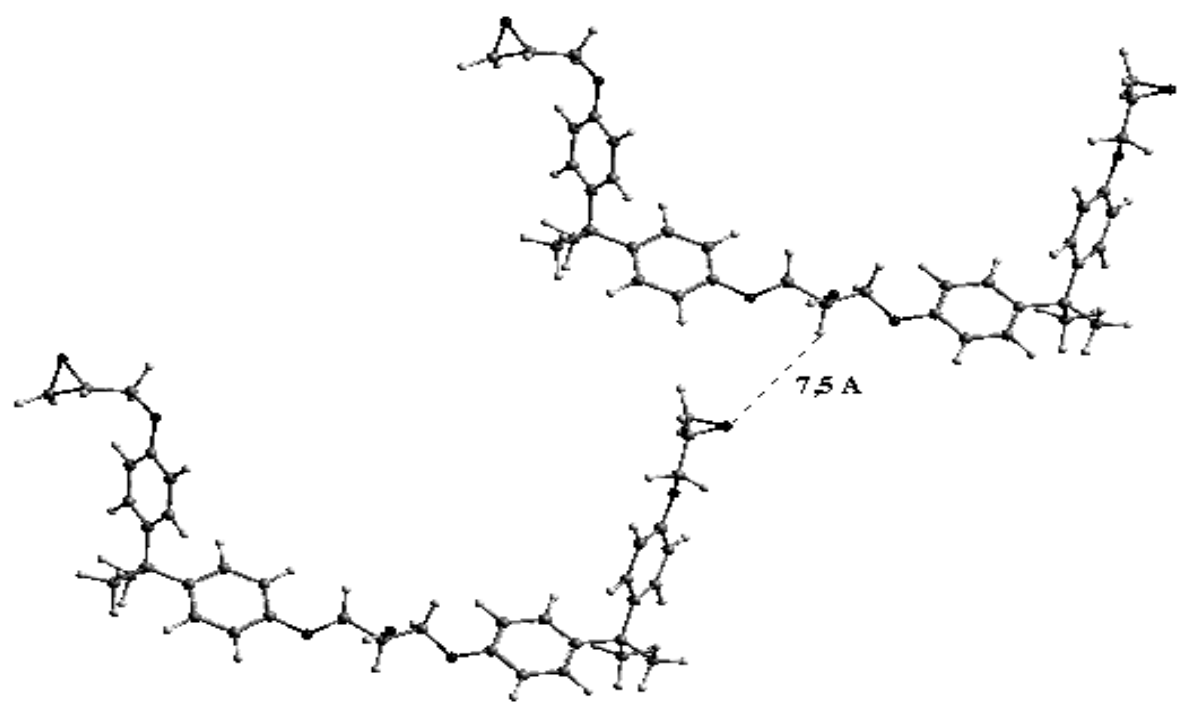

a)

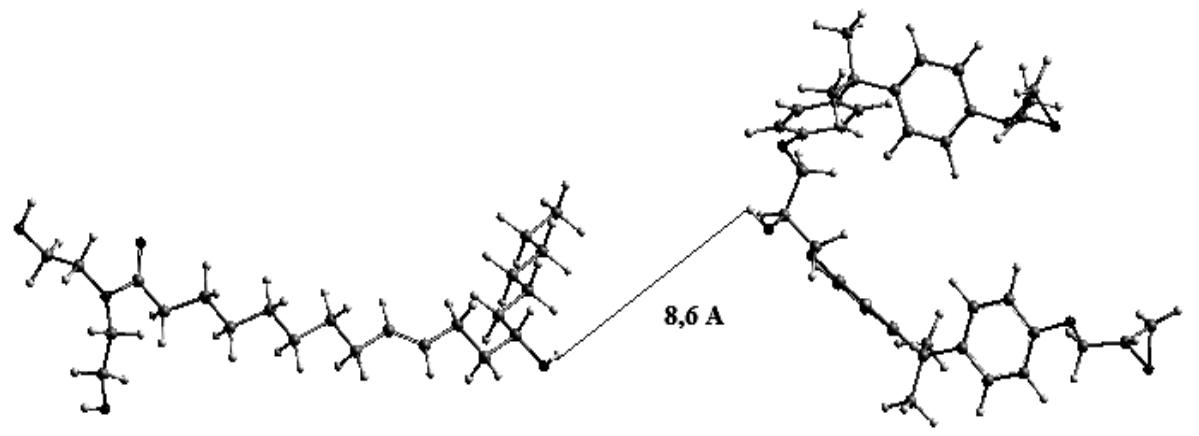

b)

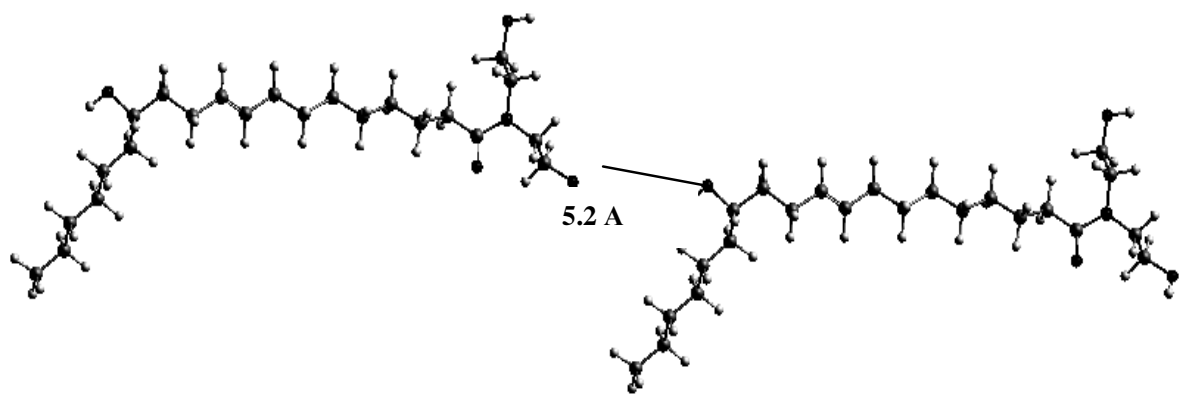

c)

Fig. 1. The three-dimensional models of molecular complexes ED-20+ED-20 (a); ED-20+Amirol M (b) and Amirol M+Amirol M (c) 
Table 3

Power and dimensional parameters of molecules and molecular complexes in the system ED-20+ Amirol M

\begin{tabular}{|l|c|c|c|c|}
\hline $\begin{array}{c}\text { Molecule or molecular } \\
\text { complex }\end{array}$ & Dipole moment $D, \mu$ & $\Delta H_{\text {formation }}, \mathrm{kJ} / \mathrm{mol}$ & $E_{\text {mutual }}, \mathrm{kJ} / \mathrm{mol}$ & $\begin{array}{c}\text { Distance between } \\
\text { molecules, }\end{array}$ \\
\hline ED-20 & 3.96 & -473.97 & - & - \\
\hline Amirol M & 4.95 & -1033.22 & - & - \\
\hline ED-20+ED-20 & 6.62 & -882.35 & 65.58 & 7.5 \\
\hline ED-20+Amirol M & 5.27 & -1507.02 & 0.17 & 8.6 \\
\hline Amirol M+Amirol M & 0.54 & -2076.73 & 10.29 & 5.2 \\
\hline
\end{tabular}

The three-dimensional images of two molecules intermolecular interactions in the diane epoxy resin and in the molecular complex ED-20+Amirol $\mathrm{M}$ as well, are received by means of the geometrical optimization. It is assumed, that the resin molecules are guided by the epoxy group of one molecule to the hydroxyl group of the other one, relatively to each other (Fig. 1a). The closest distance between them makes $7.5 \AA$. It means that, perhaps, there are no hydrogen bonds in the diane epoxy resin, as it is known, that the length of the hydrogen bond does not exceed $3 \AA$. At the same time, the calculated dipolar moment of the complex is twice as much as the isolated molecule, and the IIE energy is of rather great importance $65.58 \mathrm{~kJ} / \mathrm{mol}$. The received values don't exclude the fact of the hydrogen bond existence, which energy, as we know, does not exceed $20 \mathrm{~kJ} / \mathrm{mol}$. All these facts testify to rather intensive intermolecular IIE, which in turn, can cause high viscosity and rather big superficial tension of the diane epoxy resin. In the molecular complex ED-20+Amirol $M$ energy of interaction is three orders less than at bigger $(8.6 \AA$ ) distance between molecules (Fig. 1b). It shows much weaker IIE in the complex. The calculated value $E_{\text {mutual }}=0.17 \mathrm{~kJ} / \mathrm{mol}$ for this complex is nearly two orders less than the weakest Van der Waals' interactions $\left(E_{\text {mutual }} \sim 4 \mathrm{~kJ} / \mathrm{mol}\right)$. With reference to Fig. 1 it can be seen that the molecule of Amirol M is guided by the hydroxyl group, located in the hydrocarbonic radical chain, to the hydroxyl group of the molecule ED-20. It is obvious that this hydroxyl group has a weak basic character as it is guided to the acid hydroxyl ED-20 group and can cause a weak Brønsted acid-base IIE in the complex. Taking into consideration quite great value of Amirol M dipolar moment (4.95 D), it is possible to claim that the hydroxyl groups in the structure of dietanol groups have a weak acid character. The assumed fact is confirmed by the received three-dimensional model image of the Amirol M+Amirol M complex (Fig. 1c). The orientation of Amirol $\mathrm{M}$ molecules, relatively to each other, occurs with the hydroxyl group participation, which in turn, are the weak acids of Brønsted (in the structure of dietanol groups) and the weak Brønsted bases (the hydrocarbonic radical groups chain). Due to the small polarization in the complex $(p=0.54 \mathrm{D})$, the energy of this interaction is small $\left(E_{\text {mutual }}=10.29 \mathrm{~kJ} / \mathrm{mol}\right)$ and is comparable with weak Van der Waals' interactions. It has been assumed [11] earlier by means of rotational viscometry that the curve of a flow of a pure resin ED-20 has a pseudo-plastic character, with a small limit of fluidity about $7.6 \mathrm{~Pa}$ at $T=298 \mathrm{~K}$ and at the maximum viscosity $\eta_{\max }$ of not destroyed structure about $45 \mathrm{~Pa} \cdot \mathrm{s}$. It was realized by means of the rotational viscometry. While appending Amirol $\mathrm{M}$, the flow begins at $5.5 \mathrm{~Pa}$, whereas the value $\eta_{\max }$ is $32.7 \mathrm{~Pa} \cdot \mathrm{s}$. Further behavior of the flow curves indicates the abnormal viscosity area intensity (dynamic viscosity almost falls in steps). This area is characterized by loosely coupled pseudo-plastic structures and is shown in a very narrow area of the shift tension. The specified structures are almost destroyed and the Newtonian flow is observed for the ED-20 starting with $51.6 \mathrm{~Pa}$, and for the ED-20 system+Amirol M from 18.2 Pa. Thus, it is possible to identify the studied systems as semistructured, and the observed viscosity decrease (almost as much as twice) in the presence of Amirol $\mathrm{M}$ is caused by the weaker IIE in the system. These pilot studies are confirmed by discharged calculations with the use of the quantum and chemical modeling and the molecular complex geometrical optimization as well.

The clear confirmation of the observed effects is the research [14], doing which, the authors have studied IIE in the mixture of ED-20 and dibutyl phthalate plasticizer (DBPh). The usage of IR-spectroscopy has shown that the intensity of the absorption band of $\mathrm{OH}$ groups stretching vibrations decreases in the mixtures $\left(3000-4000 \mathrm{~cm}^{-1}\right)$. It has been assumed that both the temperature increase and the $\mathrm{DBPh}$ introduction into the resin reduce the ability of ED-20 molecules for clustering. In that case, the part of the hydroxyl groups is blocked by the active plasticizer groups, and the probability of the resin molecule associate formation decreases. It only remains to highlight the fact that the $\mathrm{OH}$-groups of the ED-20 molecule display their weak acid characteristics and the way the weak acids actively interact with the $\mathrm{DBPh}$ ester groups that have Lewis basicity. 


\subsection{The research of Superficial Fillers Characteristics}

It is known that there are active Brønsted centers of various acid force on the surface of air and dry disperse polymineral fillers, which mostly consist of oxides $\mathrm{SiO}_{2}$, $\mathrm{Fe}_{2} \mathrm{O}_{3}, \mathrm{Al}_{2} \mathrm{O}_{3}, \mathrm{TiO}_{2}, \mathrm{CaO}, \mathrm{MgO}$ [15]. These are the isolated and vitsinal hydroxyl groups with the adsorbed water molecules, weak acids and bases, which can participate in PCI with functional resin groups, modifiers and hardeners of binding.

The radiographic analysis has studied the mineral structure of the used fillers. It is assumed that the diabase powder (DP) is characterized by a wide polymineral structure, which includes the following main minerals: quartz $\left(\mathrm{SiO}_{2}\right)$, albite low $\left(\mathrm{NaAlSi}_{3} \mathrm{O}_{8}\right)$, microwedge $\left(\mathrm{KAlSi}_{3} \mathrm{O}_{8}\right)$ and the following accompanying minerals: augite $\left(\mathrm{Ca}\left(\mathrm{Mg}, \mathrm{Fe}^{3+}, \mathrm{Al}\right)(\mathrm{Si}, \mathrm{Al})_{2} \mathrm{O}_{6}\right)$, magnetite $\left(\mathrm{Fe}_{2} \mathrm{O}_{4}\right)$, horn blende and chalcopyrite $\left(\mathrm{CuFeS}_{2}\right)$. Red slime $(\mathrm{ShN})$ consists of hematite $\left(\alpha-\mathrm{Fe}_{2} \mathrm{O}_{3}\right)$ and getit $(\mathrm{FeOOH})$.

The research of the morphological features of the filler surfaces was conducted by means of the electronic and microscopic pictures of the scanning electronic microscope JSM-6390LV. The pictures are represented in Fig. 2. Apparently, the particles of the fillers have approximately identical conditionally spherical shape. It is possible toobserve some tendency of the particles to the adhesion, that is typical for the high-energy surfaces of both fillers.

The $\mathrm{pH}$-metric research of the fillers water suspensions, according to A. Nechiporenko [16] method, has shown the correlation of their chemical and mineral composition with the nature of the superficial active centers. The dependence of $\mathrm{pH}_{\text {susp }}$ from the filler contact

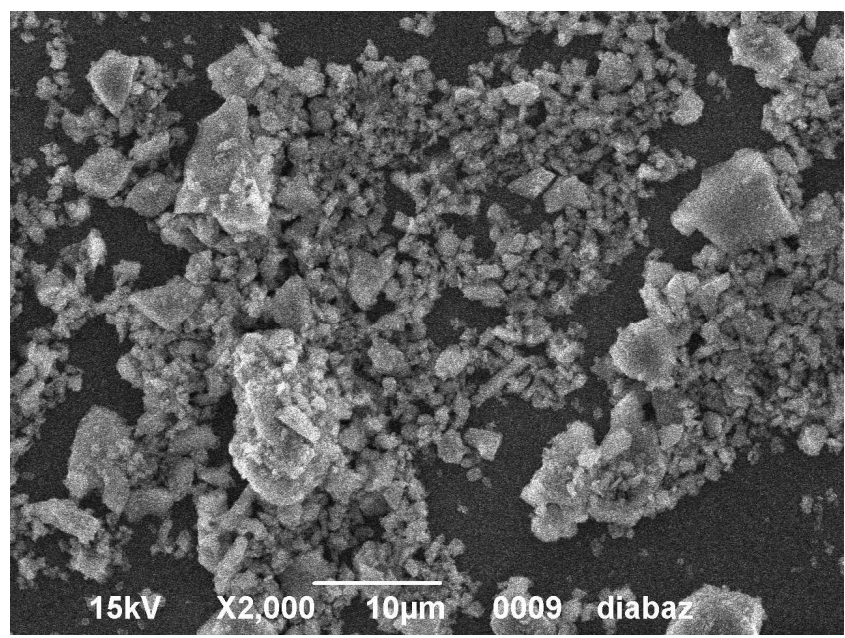

a) time with water is represented in Fig. 3. The method enables defining the general (integrated) qualitative acid and basic characteristic of the filler surface generalizing the processes of hydration, dissociation, hydrolysis and others, proceeding between the active centers of the surface and the molecules of water.

The smooth character of the curve says that the DP surface is characterized by a wider range of active centers with various functions of the acidity. Their serial interaction with water molecules proceeds slowly, and the equilibrium state, characterized by $\mathrm{pH}_{\text {susp }} \approx 8.5$ is reached only after $2-2.5 \mathrm{~h}$. Obviously, it is connected with the DP structure polyminerality. The $\mathrm{ShN}$ surface, on the contrary, has a narrow range of the active center acidity function. It can be explained by the existence of two, close by the chemical nature, Fe- containing minerals in its structure. The equilibrium state of $\mathrm{pH}_{\text {susp }} \approx 9$ in the suspension comes after $0.25-0.3 \mathrm{~h}$.

For the quantitative assessment of the superficial active Brønsted centers, the $\mathrm{pK}_{\mathrm{a}}$-photometric definition on adsorption of color indicators from water solutions was used.

Accordingly [16], the number of the surface active centers with the differentiation by $\mathrm{pK}_{\mathrm{a}}$ function, the total quantity of acid $\left(\mathrm{pK}_{\mathrm{a}}<7\right) \quad \Sigma q_{A}$ and basic $\left(\mathrm{pK}_{\mathrm{a}}>7\right) \Sigma q_{B}$ active Brønsted centers, and indicator, which enables estimating the surface, in general, as neutral $(Q \approx 1)$, acid $(Q>1)$ or basic $(Q<1)$ one, were determined. However, it is considered that, the more $Q$ value, the more acid characteristics the surface has. Hence, the less this value than 1 , the more alkaline the surface is. The results of the research are presented in Fig. 4 and Table 4.

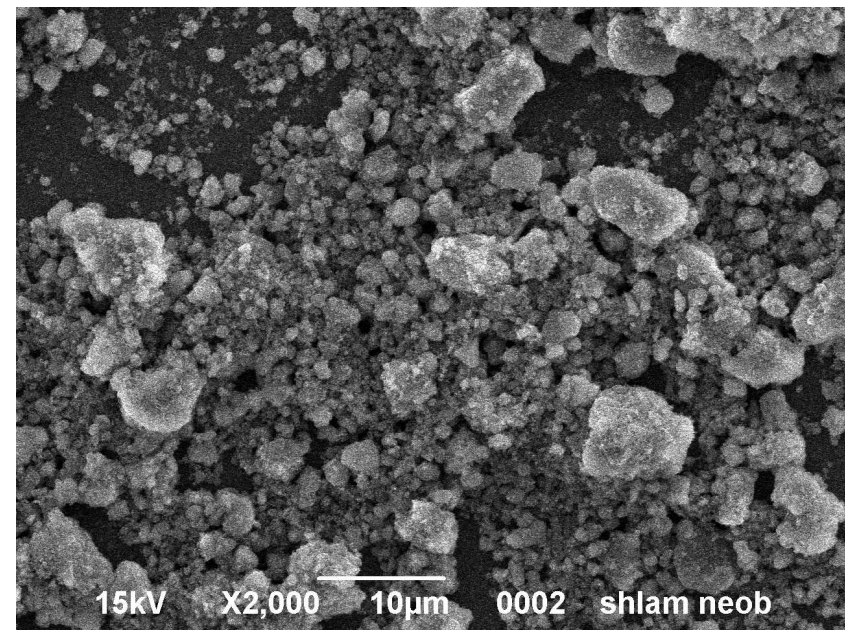

b)

Fig. 2. Electronic and microscopic images of diabase powder (a) and red slime (b) 


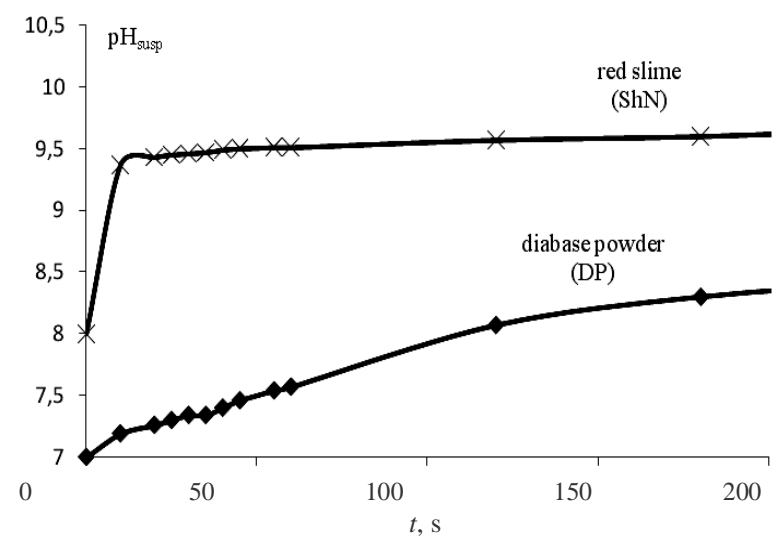

Fig. 3. $\mathrm{pH}_{\text {susp }} v s$. contact time of fillers with water

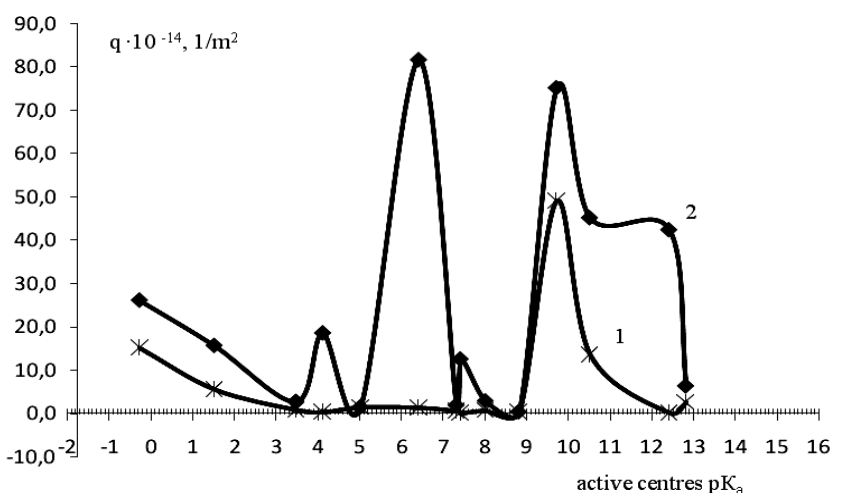

Fig. 4. The quantity of active centers on a surface of fillers: 1-red slime (ShN); 2-diabase powder (DP)

Table 4

The results of the fillers surface pK-photometric research

\begin{tabular}{|c|c|c|c|c|}
\hline Filler & $\Sigma q_{A}$ & $\Sigma q_{B}$ & $\Sigma q$ & \\
\hline DP & 148.55 & 185.23 & 333.78 & 0.80 \\
\hline ShN & 25.89 & 67.05 & 92.94 & 0.39 \\
\hline
\end{tabular}

Thus, proceeding from all above stated, it is possible to conclude that the DP surface has active centers three times as much as the $\mathrm{ShN}$ surface. According to Fig. 4, it is obvious, that the centers in the basic area of the range are characterized by the prevalence of the centers in the narrow range with $\mathrm{pK}_{\mathrm{a}} \approx 9-10$ and in the acid one, centers with $\mathrm{pK}_{\mathrm{a}} \approx 0-1.5$ prevail. It is confirmed by the data of the electrometric research obtained above. In this case, the main centers are nearly three times as much as the acid ones. That is exactly why the general strong basic character of ShN surface comes. The existence of the acid centers is obviously caused by vitsinal or strongly hydrated centers presence, which $\mathrm{pK}_{\mathrm{a}}$, as known [18], decreases with each following adsorbed water molecule.

As for DP, the electrometric research data are also confirmed. There are active centers on the surface, which are characterized by a wide $\mathrm{pK}_{\mathrm{a}}$ range. In the alkaline condition, the centers with $\mathrm{pK}_{\mathrm{a}} \approx 9-12.5$ are presented and the centers with $\mathrm{pK}_{\mathrm{a}} \approx 0-1.5$ are presented in the acid one. Unlike ShN, a high concentration of the active centers with $\mathrm{pK}_{\mathrm{a}} \approx 6-6.5$, being rather neutral or subacid, was found on the DP surface. The acid centers can be caused by either vitsinal existence or isolated active centers with several hydroxyl groups, and by the hydrated centers containing from 3 to 5 water molecules as well [15]. The general character of the DP surface is also basic.

The received values of $Q$, which are the complex characteristic of the acid-base features of the surface reasonably correlate with the $\mathrm{pH}$-metric research results: the surfaces of both fillers show the main characteristics. The ShN surface differs in bigger basicity $\left(\mathrm{pH}_{\text {susp }} \approx 9.7\right.$, $Q=0.39$ ), than DP, which can be characterized as a weakbasic one ( $\left.\mathrm{pH}_{\text {susp }} \approx 8.5, Q=0.80\right)$.

Following the obtained experimental data, and also the quantum method and chemical modeling offered in [18], the chemical formulas of the active centers main types, prevailing on the studied fillers surface (Table 5), were defined.

\subsection{Research of CPI in ED-20:Amirol M filler System}

The values of the composition dynamic viscosity ( $\mathrm{Pa} \cdot \mathrm{s}$ ) were measured at the temperature of $298 \mathrm{~K}$ on the basis of ED-20 resin, Amirol M and fillers to research the CPI nature and character on the interphases. Amirol M was added into the composition in two ways. Way A: the resin was mixed up with Amirol $\mathrm{M}$ (1 wt \% of the resin weight) up to the homogeneous mass formation (a resin part), to which the filler was added. Way B: the filler, which surface was modified previously by Amirol M, was introduced into the resin. The filler was introduced into the composition in the quantity of $\omega=20$ and 40 mass parts per 100 mass parts of pure resin or resin part. The results of the measurements are presented in Table 6. As a result of rheological researches, it is assumed that the introduction of disperse mineral fillers into ED-20 or ED-20+Amirol M system leads to the dilatant-Newtonian 
structure formations with the low-leveled viscosity in a wide range of the shift tension. Such behavior, as it has already been mentioned, is connected with the volume, diffusive phenomena in the system, and some of molecule binding interactions with the filler on the interphases as well.

Analyzing the data in Table 6, it is possible to claim that while introducing fillers into pure resin, the dynamic viscosity of the compositions grows, and the dependence of the curve $\eta=f(\omega)$ for the ED-20+DP system has a tilt angle (0.28), which is 1.5 times as much as for the ED-20+ShN system (0.19). The raised structure degree is, obviously, connected with more intensive interaction of the DP surface with the resin molecules. Taking into consideration the fact that the specific surface of ShN $\left(11.35 \mathrm{~m}^{2} / \mathrm{g}\right)$ exceeds DP $\left(1.90 \mathrm{~m}^{2} / \mathrm{g}\right)$ five times as much, it is possible to assume, that the interphase area of the contact in the first case will be far more and, therefore, the interaction has to be a lot more intensive, if the volume processes are considered. However, the obtained data of the rheological researches confirm the opposite effect. Hence, taking into account the data of the rheological experiment, it is possible to conclude that PCI between the functional groups on the interphase are the defining factors in the structuring processes of these systems. Consequently, the PCI nature and intensity will mainly depend on the quantity and acid key parameters of the functional groups and the active centers.

The received conclusion is confirmed by the rheological experiment data. On the one hand, the DP surface, that contains the number of the active centers three times as much, interacts with the resin much more intensively, than the ShN surface does. On the other hand, it is reasonably to connect this idea with the fact that the subacid hydroxyl groups of the resin interact more actively with the strong-basic active centers, that have $\mathrm{pK}_{\mathrm{a}}=10-13$, and which quantity on the DP surface exceeds almost twice as much as on $\mathrm{ShN}$ surface.

It is possible to analyze the contribution of the diffusive processes to the studied systems structuring by the rheological characteristics of ED-20+Amirol M+filler system consideration. In the system without any filler, the essential plasticizing effect of the modifier, which becomes apparent in the dynamic viscosity of the resin decreases 1.5 times as much, as can be observed. The dynamic viscosity of the systems grows with the formation of weaker structures while appending the fillers. In the high-filled compositions (40 mass parts) Amirol M presence almost does not have an effect on the absolute viscosity values. It is apparent that the molecule of the modifier partially loses the plasticizing effect in the filled systems, and it is, clearly, connected with their diffusion to the surface of the fillers. The diffusive phenomena, as known, have a competitive character. Therefore, in spite of the fact that the molecular mass of Amirol M is commensurable with the molecular mass of the resin, its diffusion is facilitated by the spatial linear structure of the molecule without branching. And, the main driving forces of the diffusive processes are, apparently, acid-basic interactions between $\mathrm{OH}$-Amirol $\mathrm{M}$ groups and the active centers of the surfaces. As it has been shown before, the existence of the hydroxyl groups of various acid forces in its molecule can motivate its behavior both like a weak acid and like a weak basis of Brønsted.

In the ShN mixtures, the diffusion of Amirol M molecules has a more intensive character than in DP compositions. It follows from the fact that, a tilt angle of the curve dependence $\eta=f(\omega)$ for ED-20+Amirol M+DP (0.30) system is more than that for the ED-20+Amirol M+RS system (0.23). The facilitated diffusive process can be connected with the diffusive way reduction of the molecules, expressed by means of the way curvature factor $\tau$ equal to the lengths relation through the filled and unfilled polymer. For spherical particles $\tau \approx 1+v_{f} / 2$, where $v_{f}-$ a volume fraction of a filler [3]. This hypothesis is supported by the calculated values $\tau$ for the ShN compositions (1.034-1.063), which have smaller values than for the DP ones (1.039-1.070). It is also necessary to note that the way, Amirol M was introduced to the composition, does not almost influence the structuring processes. It also proves the fact that the modifier molecules diffuse to the filler surface.

Table 5

The results of the fillers surface research

\begin{tabular}{|c|c|c|}
\hline Filler & Types of the active centers prevailing on a surface & $\mathrm{pK}_{\mathrm{a}}$ of centers prevailing on a surface \\
\hline \multirow{5}{*}{ Diabase powder (DP) } & $\mathrm{SiO}(\mathrm{OH})_{3} \mathrm{H}_{2} \mathrm{O}$ & \\
& $\mathrm{SiO}_{2}(\mathrm{OH})_{2}\left(\mathrm{H}_{2} \mathrm{O}\right)_{2}$ & 1.5 \\
& $\mathrm{SiO}_{3}(\mathrm{OH})\left(\mathrm{H}_{2} \mathrm{O}\right)_{3}$ & 6.5 \\
& $\mathrm{AlO}_{3}(\mathrm{OH})_{3} \mathrm{H}_{2} \mathrm{O}$ & $10.0-12.5$ \\
& $\mathrm{AlO}_{3}(\mathrm{OH})_{3}$ & \\
\hline \multirow{3}{*}{ Red slime (ShN) } & $\mathrm{FeO}_{4}(\mathrm{OH})_{2}$ & 1.5 \\
& $\mathrm{Fe}_{2} \mathrm{O}_{9}(\mathrm{OH})_{2}\left(\mathrm{H}_{2} \mathrm{O}\right)_{2}$ & $9.5-11.5$ \\
\hline & $\mathrm{FeO}_{3}(\mathrm{OH})_{3}\left(\mathrm{H}_{2} \mathrm{O}\right)_{2}$ & \\
& $\mathrm{FeO}_{4}(\mathrm{OH})_{2} \mathrm{H}_{2} \mathrm{O}$ & \\
\hline
\end{tabular}


Dynamic viscosity of compositions

\begin{tabular}{|c|c|c|}
\hline $\begin{array}{ll}\text { Filler } & \text { Resin part } \\
\end{array}$ & ED-20 & ED-20+Amirol M \\
\hline- & $7.63 \pm 0.30$ & $4.71 \pm 0.19$ \\
\hline DP 20 mass parts (way A) & $14.60 \pm 0.58$ & $9.54 \pm 0.38$ \\
\hline DP 40 mass parts (way A) & $19.08 \pm 0.76$ & $16.83 \pm 0.67$ \\
\hline DP 20 mass parts (way B) & $15.71 \pm 0.63$ & - \\
\hline DP 20 mass parts (way B) & $20.76 \pm 0.83$ & - \\
\hline ShN 20 mass parts (way A) & $13.47 \pm 0.54$ & $10.66 \pm 0.43$ \\
\hline ShN 40 mass parts (way A) & $14.84 \pm 0.59$ & $14.03 \pm 0.56$ \\
\hline
\end{tabular}

\section{Conclusions}

Thus, the structuring processes are defined by the acid-basic interactions in the volume and on the interphases of the investigated diane epoxy resins with disperse oxide materials, which are proved by theoretical and experimental ways. It is assumed that the hydroxyl groups in an epoxy resin molecule show weak acid features. They interact with the hydroxyl groups of the modifier or the filler active centers of the main or strongbasic character in the compositions. It is shown that the acid-basic interactions on the interphases play the main role in the structuring processes. It is also assumed that the intensity of the diffusive phenomena is defined by the acid force of the filler hydroxyl groups whereas the share of the volume effects is small.

\section{References}

[1] Zaitsev Yu., Kochergin Yu., Pakter M., Kucher R.: Epoksidnye Oligomery i Kleyevye Kompozitsyy. Naukova dumka, Kyev 1990. [2] Lipatov Yu. (Ed.) : Fizyko-Khimiia Mnogokomponentnykh Polimernykh system. 1. Napolnennye Polimery. Naukowa dumka, Kyev 1986.

[3] Chernin I., Smekhov F., Zherdev Yu.: Epoksidnye Polimery i Kompozitsii. Khimiya, Moskva 1982.

[4] Pykhtin A., Surikov P., Kandyrin L. et al.: Vestnik MITKhT, 2013, 8, 113.

[5] Zakordonskii V., Skladaniuk R.: Vysokomol. Soed. A, 2001, 43, 1173.

[6] Mezhikovskii S., Vasilchenko Ye., Repina T.: Vysokomol. Soed. B, 1995, 37, 887.

[7] Kamenskii A.: IV Vseros. Nauchn. Konf. "Fizikokhimiia protsessov pererabotki polimerov", Rossiya, Ivanovo 2009, 179.

[8] Danchenko Yu., Popov Yu., Barabash Ye.: Vopr. Khim. Khim. Tekhnol., 2016, 3, 53.

[9] Starostina I., Stoianov O.: Kislotno-Osnovnye Vzaimodeystviia v Metallpolimernykh Sistemakh. Izd-vo Kazan. Univ., Kazan 2010.
[10] Yakovleva R., Kachomanova M., Bykov R. et al.: Nauk.

Visnyk Budivnytstva, 2010, 60, 359.

[11] Yakovleva R., Danchenko Yu., Kachomanova M. et al.: Nauk. Visnyk Budivnytstva, 2007, 43, 100.

[12] Klark T.: Kompiuternaia Khimiia: Prakticheskoye

Rukovodstvo po Raschetam Struktury i Energii Molekuly. Mir, Moskva 1990.

[13] Yudin A. (Ed.): Laboratornyi Praktikum "Kvantovo-

Khimicheskoye Modelirovaniye Soyedinenii v Pakete HyperChem". Kemerovo 2013.

[14] Tiulina R., Chernin I., Zvereva G. et al.: Plast. Massy, 1989, 4, 62.

[15] Tarasevich Yu.: Poverkhnostnye Yavleniya na Dispersnykh Materialakh. Naukova dumka, Kyev 2011.

[16] Danchenko Yu., Kachomanova M.: Nauk. Visnyk

Budivnytstva, 2016, 86, 164.

[17] Danchenko Yu.: Slovak Int. J., 2017, 3, 15.

Received: April 06, 2017 / Revised: July 30, 2017 / Accepted: September 04, 2017

\section{РОЛЬ КИСЛОТНО-ОСНОВНИХ ВЗАЕМОДІЙ В ПРОЦЕСАХ СТРУКТУРУВАННЯ НАПОВНЕНОЇ ДІАНОВОЇ ЕПОКСИДНОЇ СМОЛИ}

Анотація. За допомогою методу ротаиійної віскозиметрії вивчені прочеси структурування в діановій епоксидній смолі марки ЕД-20, яка містить дисперсні оксидні наповнювачі та модифікатори. Показано, щзо визначальну роль в цих прочесах відіграють кислотно-основні взаємодї між функиійними групами молекул смоли $і$ активними центрами поверхні наповнювачів. Ступінь структурування визначається як загальним числом активних иентрів поверхні, так $i$ ї значенням $p K_{a}$. Встановлено, щуо інтенсивність дифузійних явищ визначається кислотною силою гідроксильних груп наповнювачів, в той час як частка об'ємних ефектів в композиціях невелика.

Ключові слова: діанова епоксидна смола, дисперсійний оксидний наповнювач, кислотно-основні взаємодії, активний иентр, динамічна в'язкість. 